\title{
Legal GAP antara Pemilik Tanah dan Aparat Menimbulkan Sengketa dalam Pengadaan Tanah Untuk Kepentingan Umum (Studi Kasus di Bengkulu)
}

\author{
Yanto Sufriadi \\ Fakultas Hukum Universitas Hazairin Bengkulu \\ Jl. Jenderal Ahmad Yani No. 1 Bengkulu \\ E-mail : yanto_sufriadi@yahoo.co.id
}

\begin{abstract}
The research focuses on the legal definition of land procurement for public use that caused many disputes in the past. The problem studied here is the understanding on public interest, land rights, and proper indemnification of the land owners and the land procurement acting authorities. This research is qualitative research with socio legal approach using constructivism paradigm. The research used data from field study and literature study. The findings conclude that the dispute on the land procurement for public use was caused by injustice because of legal understanding gap between the land owners who viewed law as traditions and values prevailing in society and the land procurement acting authorities who viewed law in form of regulations which was comprehended only in formal-textual context.
\end{abstract}

Key words : Land procurement, public use, dispute

\begin{abstract}
Abstrak
Penelitian ini difokuskan pada pemaknaan hukum dalam pengadaan tanah untuk kepentingan umum, yang di masa lalu banyak menimbulkan sengketa. Permasalahan yang dikaji adalah mengenai pemaknaan pemilik tanah dan aparat pelaksana pengadaan tanah tentang kepentingan umum, hak atas tanah dan ganti kerugian yang layak. Penelitian ini menggunakan jenis penelitian kualitatif dan pendekatan socio legal approach, dengan paradigma konstruktivisme. Penelitian ini menggunakan data hasil studi lapangan dan kepustakaan. Hasil penelitian ini menyimpulkan bahwa sengketa pengadaan tanah untuk kepentingan umum disebabkan oleh ketidak-adilan, karena terjadinya gap pemaknaan tentang hukum antara pemilik tanah yang memandang hukum sebagai tradisi dan nilainilai yang hidup dalam masyarakat, dengan pemaknaan aparat pelaksana pengadaan tanah yang memandang hukum dalam bentuknya sebagai peraturan perundang-undangan dan hanya dipahami secara formal-tekstual.
\end{abstract}

Kata Kunci : Pengadaan tanah, kepentingan umum, sengketa. 


\section{Pendahuluan}

Pengadaan tanah yang dilakukan oleh pemerintah untuk memenuhi kebutuhan tanah (permukaan bumi) dalam pembangunan fasilitas umum, seringkali menimbulkan konflik dengan masyarakat pemilik tanah. Kegiatan pemerintah tersebut berpangkal pada kewenangan yang diberikan kepada negara sebagaimana diatur dalam Pasal 33 ayat (3) UUD NRI 1945. ${ }^{1}$ Alasan mengapa bumi dan air dan kekayaan alam yang terkandung di dalamnya itu harus dikuasai oleh negara adalah karena bumi, air dan kekayaan alam yang terkandung di dalamnya itu merupakan pokok-pokok kemakmuran rakyat. ${ }^{2}$

Berkaitan dengan kewenangan ini, untuk menyelenggarakan penyediaan tanah bagi berbagai keperluan masyarakat dan negara, pemerintah dapat mencabut hakhak atas tanah dengan memberikan ganti kerugian yang layak menurut cara yang diatur dengan undang-undang ${ }^{3}$, apabila upaya melalui cara musyawarah gagal membawa hasil. ${ }^{4}$

Dengan adanya keharusan bermusyawarah dan keharusan pemberian ganti kerugian yang layak dalam pengadaan tanah untuk kepentingan umum tersebut, seharusnya tidak akan menimbulkan sengketa, akan tetapi di dalam praktik begitu banyak sengketa yang terjadi dalam pengadaan tanah untuk kepentingan umum tersebut. $^{5}$

Pada masa Orde Baru hingga tahun 2001, tercatat sebanyak 1.497 kasus sengketa, dengan luas lahan yang menjadi obyek sengketa mencapai 1.052.514,37 hektar, dan jumlah anggota masyarakat yang menjadi korban sebanyak 232.177 Kepala Keluarga (KK). ${ }^{6}$ Data lainnya menyebutkan banwa pada akhir 2001 tercatat sebanyak 1.753 kasus sengketa. ${ }^{7}$ Kemudian pada 2007 meningkat menjadi sebanyak 2.810 kasus. ${ }^{8}$

${ }^{1}$ Dalam Pasal 33 Ayat (3) UUD NRI 1945, disebutkan bahwa bumi, air dan kekayaan alam yang terkandung di dalamnya dikuasai oleh negara dan dipergunakan untuk sebesar-besarnya kemakmuran rakyat.

${ }^{2}$ Penjelasan Pasal 33 UUD NRI 1945

${ }^{3}$ Pasal 18 UU No. 5 Tahun 1960

${ }^{4}$ Penjelasan Umum UU No.20 Tahun 1961 tentang Pencabutan Hak-Hak Atas Tanah dan Benda-Benda yang Ada Di Atasnya.

${ }^{5}$ Sengketa, menurut Kamus Lengkap Bahasa Indonesia, adalah perselisihan, pertikaian, perkara (dalam pengadilan); sesuatu yang menyebabkan perbedaan pendapat, pertengkaran pendapat, pembantahan.

${ }^{6}$ Jayadi Damanik, Pembaruan Agraria dan Hak. Asasi Petani, Lapera Pustaka, Yogyakarta, 2002, hlm. 22-23.

${ }^{7}$ Maria S.W Sumardjono, Tanah dalam Perspektif Hak Ekonomi Sosial dan Budaya, Penerbit Buku Kompas, Jakarta, 2009, hlm. 111.

${ }^{8}$ Badan Pertanahan Nasional RI, REFORMA AGRARIA Mandat Politik, Konstitusi dan Hukum dalam Rangka Mewujudkan Tanab untuk Keadilan dan Kesejabteraan Rakyat, 2007, hlm. 1. 
Berdasarkan hasil penelitian penulis terdahulu, ${ }^{9}$ sengketa yang muncul dalam pengadaan tanah tersebut, disebabkan karena substansi hukum pertanahan nasional bersifat sentralistik sehingga mendesak hukum adat, struktur hukum pelaksana pengadaan tanah untuk kepentingan umum menggunakan prosedur yang kaku dan bersifat mekanis, serta budaya hukum aparat yang berorientasi Legal Positivism. Penyebab sengketa yang demikian memerlukan penelitian lebih lanjut, terutama untuk menjelaskan pemaknaan para pihak tentang hukum dalam pengadaan tanah untuk kepentingan umum tersebut.

\section{Rumusan Masalah}

Berdasarkan uraian yang telah dikemukakan di atas, penelitian ini difokuskan pada pemaknaan tentang hukum antara pemilik tanah dan aparat pelaksana pengadaan tanah untuk kepentingan umum, yang berujung pada terjadinya sengketa. Kemudian untuk mengeksplorasi fokus studi tersebut, dalam penelitian ini diajukan tiga permasalahan, yaitu : Pertama, bagaimanakah pemaknaan pemilik tanah dan aparat pelaksana pengadaan tanah tentang kepentingan umum? Kedua, bagaimanakah pemaknaan pemilik tanah dan aparat pelaksana pengadaan tanah untuk kepentingan umum tentang hak atas tanah? Ketiga, bagaimanakah pemaknaan pemilik tanah dan aparat pelaksana pengadaan tanah untuk kepentingan umum tentang ganti kerugian yang layak dalam pengadaan tanah untuk kepentingan umum?

\section{Tujuan Penelitian}

Penelitian ini bertujuan untuk mengetahui dan menjelaskan tentang: Pertama, bagaimana pemaknaan pemilik tanah dan aparat pelaksana pengadaan tanah untuk kepentingan umum tentang hukum; Kedua, tentang hak atas tanah dan, Ketiga, tentang ganti kerugian yang layak, yang selama ini telah menimbulkan banyak sengketa dan apa yang perlu dilakukan untuk mencegah atau meminimalisir sengketa dalam pengadaan tanah untuk kepentingan umum di masa depan.

${ }^{9}$ Lihat Yanto Sufriadi, Penyebab Sengketa Pengadaan Tanah untuk Kepentingan Umum (Studi Kasus Sengketa Pengadaan Tanah untuk Kepentingan Umum di Bengkulu), Jurnal Hukum Ius Quia Iustum, No.1 Vol.18 Januari 2011, hlm 61. 


\section{Metode Penelitian}

Metode yang digunakan dalam penelitian ini adalah socio-legal approach yang bersifat kualitatif, dengan menggunakan paradigma konstruktivisme. Penelitian ini menggunakan dua pendekatan, yaitu pendekatan sosial dan pendekatan yuridis normatif. Pendekatan sosial dipergunakan untuk menganalisis sikap, pandangan dan tindakan aktor dalam praktik pengadaan tanah untuk kepentingan umum. Sedangkan pendekatan yuridis normatif dipergunakan untuk menganalisis norma peraturan perundang-undangan dengan mengacu pada nilai-nilai kesejahteraan dan keadilan dalam masyarakat. Analisis yang dilakukan bersifat kualitatif yang tidak menekankan pada kuantitas data, melainkan pada kualitasnya. Data primer diperoleh melalui wawancara, sedangkan data sekunder diperoleh melalui penelusuran dokumen perundang-undangan, buku, jurnal, hasil-hasil penelitian sebelumnya dan putusan pengadilan.

\section{Hasil Penelitian dan Pembahasan}

\section{Pemaknaan Pemilik Tanah dan Aparat Pelaksana Pengadaan Tanah tentang Kepentingan Umum}

Kepentingan umum merupakan tujuan yang ingin dipenuhi dan sekaligus menjadi alasan pemberian wewenang kepada negara untuk mengambil tanah yang dimiliki perorangan maupun hak ulayat yang dimiliki masyarakat hukum adat. Karena itu, pemaknaan tentang kepentingan umum menjadi sangat penting dalam kegiatan pengadaan tanah untuk kepentingan umum. Perbedaan pemaknaan tentang kepentingan umum antara aparat pelaksana pengadaan tanah dengan pemilik hak atas tanah, bangunan atau tanaman, dapat memunculkan perilaku dan sikap yang mengakibatkan terjadinya sengketa.

J.J. Rousseau, mengemukakan bahwa kepentingan umum merupakan kepentingan masyarakat yang setiap individu tidak dapat melaksanakannya sendirisendiri..$^{10}$ Sementara Van Wijk mengemukakan bahwa kepentingan umum adalah tuntutan hukum masyarakat yang harus dilayani oleh pemerintah, demi terwujudnya kesejahteraan masyarakat. ${ }^{11}$ Sedangkan Koentjoro Poerbopranoto,

\footnotetext{
${ }^{10}$ Von Schmid, Abli Pemikir Besar Negara dan Hukum, Pembangunan, Jakarta, 1954, hlm. 62.

${ }^{11}$ Van Wijk dalam Koentjoro Porbopranoto, Sedikit tentang Sistem Pemerintahan Demokrasi, Universitas Airlangga, Surabaya, 1956, hlm. 37.
} 
mengartikan kepentingan umum meliputi kepentingan bangsa, masyarakat, dan negara. Kepentingan umum mengatasi kepentingan individu, kepentingan golongan dan daerah. ${ }^{12}$ Namun demikian, menurut Notonagoro, meskipun kepentingan umum mengatasi kepentingan individu, bukan berarti negara tidak mengakui kepentingan individu. Kepentingan individu tercakup dalam kepentingan umum yang bertumpu pada keadilan sosial. ${ }^{13}$

Berdasarkan pendapat yang dikemukakan di atas, secara substantif dapat ditarik pengertian bahwa kepentingan umum merupakan kepentingan yang diperlukan untuk mensejahterakan masyarakat banyak, yang dilayani pemenuhannya oleh pemerintah, yang didalamnya tetap memberikan pengakuan dan perlindungan terhadap hak-hak individu.

Berkaitan dengan pengadaan tanah, di dalam Undang-Undang Pokok Agraria (UUPA), disebutkan bahwa untuk kepentingan umum, termasuk kepentingan bangsa dan negara serta kepentingan bersama dari rakyat, hak-hak atas tanah dapat dicabut dengan memberi ganti kerugian yang layak. ${ }^{14}$ Wewenang untuk mencabut hak-hak atas tanah tersebut dilimpahkan kepada Presiden, ${ }^{15}$ yang tidak dapat didelegasikan kepada Pejabat lainnya. ${ }^{16}$ Pencabutan dapat dilakukan terhadap hak atas tanah perorangan $^{17}$ maupun hak ulayat yang dikuasai oleh masyarakat hukum adat. ${ }^{18}$

Akan tetapi apa pengertian kepentingan umum, kepentingan bangsa dan negara serta kepentingan bersama dari rakyat tersebut, tidak dijelaskan dalam UUPA maupun dalam UU No. 20 Tahun 1961 tentang Pencabutan Hak-Hak atas Tanah dan Benda-Benda yang Ada di Atasnya. ${ }^{19}$ Undang-undang ini justeru menambah alasan baru bahwa pencabutan hak atas tanah juga dapat dilakukan demi kepentingan pembangunan. ${ }^{20}$

Dalam Instruksi Presiden (Inpres) Republik Indonesia Nomor 9 Tahun $1973^{21}$ juga hanya menjelaskan: Pertama, suatu kegiatan dalam rangka pelaksanaan

\footnotetext{
${ }^{12}$ Ibid.

${ }^{13}$ Notonagoro, Pancasila Falsafah Negara, Penerbit Airlangga, Surabaya, 1961, hlm. 11.

${ }^{14}$ Pasal 18 UU No. 5 Tahun 1960 tentang Peraturan Dasar Pokok-Pokok Agraria.

${ }^{15}$ Pasal 1 UU No. 20 Tahun 1961 tentang Pencabutan Hak-Hak Atas Tanah dan Benda-Benda Yang Ada Di Atasnya.

${ }^{16}$ Penjelasan Umum angka (4) huruf a dan b UU No. 20 Tahun 1961 tentang Pencabutan Hak-Hak Atas Tanah dan Benda-Benda Yang Ada Di Atasnya.

${ }^{17}$ Penjelasan Umum angka (2) UU No. 20 Tahun 1961.

${ }^{18}$ Penjelasan Umum angka II angka (3) UU No. 5 Tahun 1960.

${ }^{19}$ UU No. 20 Tahun 1961 tentang Pencabutan Hak-Hak Atas Tanah dan Benda-Benda yang Ada Di Atasnya.

${ }^{20}$ Pasal 1 UU No. 20 Tahun 1961.

${ }^{21}$ Inpres No. 9 Tahun 1973 tentang Pedoman-Pedoman Pelaksanaan Pencabutan Hak-Hak Atas Tanah dan Benda-Benda Yang Ada Di Atasnya.
} 
pembangunan mempunyai sifat kepentingan umum, apabila kegiatan tersebut menyangkut: kepentingan bangsa dan negara, dan/atau kepentingan mayarakat luas, dan atau kepentingan rakyat banyak/bersama, dan atau kepentingan pembangunan..$^{22}$ Namun apa yang dimaksudkan dengan masing-masing kepentingan tersebut, sama sekali tidak dijelaskan. Kedua, bentuk-bentuk kegiatan pembangunan yang mempunyai sifat kepentingan umum tersebut meliputi 13 bidang kegiatan. ${ }^{23} \mathrm{Ketiga}$, suatu proyek pembangunan dinyatakan mempunyai sifat kepentingan umum, apabila sebelumnya sudah termasuk dalam Rencana Pembangunan yang telah diberitahukan kepada masyarakat yang bersangkutan. Jika suatu Proyek Pembangunan Daerah akan dinyatakan mempunyai bentuk kegiatan yang bersifat kepentingan umum, maka sebelumnya proyek tersebut harus sudah termasuk dalam Rencana Induk Pembangunan dari daerah yang bersangkutan dan yang telah mendapat persetujuan Dewan Perwakilan Rakyat Daerah setempat. Rencana Induk Pembangunan tersebut harus bersifat terbuka untuk umum. ${ }^{24}$ Keempat, yang berwenang melakukan pencabutan adalah Presiden, dan Kelima, yang berhak menjadi subyek atau pemohon untuk mengajukan permintaan pencabutan hak atas tanah adalah instansi Pemerintah maupun usaha swasta, dengan memperhatikan persyaratan untuk memperoleh hak atas tanah sesuai dengan ketentuan yang berlaku. Bagi usaha swasta, rencana proyeknya harus disetujui oleh Pemerintah atau Pemerintah Daerah. ${ }^{25}$

Berdasarkan kriteria kepentingan umum, sebagaimana yang telah dikemukakan di atas, maka konsep kepentingan umum dalam pencabutan hak atas tanah di Indonesia, tidak hanya diekspresikan melalui kombinasi Pedoman Umum (General Guide) dan Ketentuan-ketentuan Daftar (list Provisions) sebagaimana yang dikemukakan oleh Michael G Kitay, ${ }^{26}$ melainkan juga diekspresikan dengan menentukan ciri atau persyaratan bahwa bentuk kegiatan pembangunan yang bersifat kepentingan umum itu harus termasuk dalam rencana pembangunan yang sudah disetujui oleh Dewan Perwakilan Rakyat yang terkait, bersifat terbuka untuk

\footnotetext{
${ }^{22}$ Pasal 1 ayat (1) Inpres No.9 Tahun 1973.

${ }^{23}$ Pasal 1 ayat (2) dan (3) Inpres No.9 Tahun 1973 tentang Pedoman-Pedoman Pelaksanaan Pencabutan HakHak Atas Tanah dan Benda-Benda yang Ada Di Atasnya.

${ }^{24}$ Pasal 2 ayat (1), (2) dan (3) Inpres No.9 Tahun 1973.

${ }^{25}$ Pasal 3 ayat (1) dan (2) Inpres No.9 Tahun 1973 tentang Pedoman-Pedoman Pelaksanaan Pencabutan HakHak Atas Tanah dan Benda-Benda Yang Ada Di Atasnya.

${ }^{26}$ Michael G. Kitay, dalam Oloan Sitorus dan Dayat Limbong, Pengadaan Tanah Untuk. Kepentingan Umum, Cetakan Pertama, Mitra Kebijakan Tanah Indonesia, Yogyakarta, 2004, hlm. 8.
} 
umum dan kegiatannya selain dilakukan oleh pemerintah juga dapat dilakukan oleh badan-badan swasta.

Dalam Permendagri No. 15 Tahun 1975 tentang Tata Cara Pembebasan Tanah (melalui musyawarah), pengertian tentang kepentingan umum sebagai alasan dilakukannya pembebasan tanah tidak dirumuskan. Namun demikian, apabila memperhatikan pertimbangan dari ditetapkannya Permendagri tersebut, dapat diketahui bahwa alasan dilakukannya pembebasan tanah adalah untuk memenuhi kebutuhan tanah dalam usaha-usaha pembangunan, baik yang dilakukan oleh instansi pemerintah maupun oleh swasta. ${ }^{27}$ Dengan demikian makna kepentingan umum dalam Permendagri No.15 Tahun 1975 identik dengan kepentingan pembangunan, baik yang dilakukan oleh pemerintah maupun swasta. Wewenang untuk melakukan pembebasan tanah diberikan kepada Panitia Pembebasan Tanah yang dibentuk oleh Gubernur, ${ }^{28}$ sedangkan bentuk kegiatan dan persyaratan kegiatan pembangunan yang menjadi alasan pembebasan tanah tidak ditentukan.

Dalam Permendagri No. 2 Tahun 1985, ${ }^{29}$ pengertian tentang kepentingan umum juga tidak dirumuskan secara eksplisit, tetapi dapat diketahui dari pertimbangan munculnya Permendagri tersebut adalah dalam rangka mensukseskan pembangunan nasional, khususnya pembangunan di Wilayah Kecamatan, diperlukan adanya ketentuan-ketentuan khusus mengenai pengadaan tanah bagi proyek-proyek pembangunan berskala kecil dan tidak memerlukan tanah yang luas, (tidak lebih dari 5 hektar) yang dilakukan oleh instansi pemerintah. ${ }^{30}$ Dengan demikian makna kepentingan umum adalah kepentingan pembangunan, sama dengan pengertian kepentingan umum dalam Permendagri No.15 Tahun 1975.

Berdasarkan kriteria tersebut di atas, maka pengertian kepentingan umum dalam pengadaan tanah melalui pembebasan, hanya diekspresikan : Pertama, dalam bentuk Pedoman Umum (General Guide) bahwa sifat kepentingan umum diidentikkan dengan kegiatan pembangunan, tetapi apakah yang dimaksud dengan kegiatan pembangunan tersebut, tidak dijelaskan. Kedua, ciri atau persyaratan kegiatan

\footnotetext{
${ }^{27}$ Bagian "Menimbang” Permendagri No.15 Tahun 1975 tentang Ketentuan-Ketentuan Mengenai Tata Cara Pembebasan Tanah.

${ }^{28}$ Pasal 4 Permendagri No.15 Tahun 1975 tentang Ketentuan-Ketentuan Mengenai Tata Cara Pembebasan Tanah.

${ }^{29}$ Permendagri No.2 Tahun 1985 tentang Tata Cara Pengadaan Tanah Untuk Keperluan Proyek Pembangunan Di Wilayah Kecamatan

${ }^{30}$ Bagian "Menimbang” Permendagri No. 2 Tahun 1985 tentang Tata Cara Pengadaan Tanah Untuk Keperluan Proyek Pembangunan Di Wilayah Kecamatan
} 
kepentingan umum, dapat dilakukan oleh pemerintah maupun oleh badan-badan swasta. Pengekspresian kepentingan umum yang demikian, memiliki cakupan yang sangat luas dan hampir tanpa batas, sebab setiap pembangunan, apapun bentuknya dan siapapun pelaksananya, dapat dianggap sebagai kepentingan umum.

Dalam perkembangannya, kedua Permendagri tersebut di atas dicabut dan digantikan dengan Keppres No. 55 Tahun 1993 tentang Pengadaan Tanah Bagi Pelaksanaan Pembangunan Untuk Kepentingan Umum. Dalam Keppres ini, pengertian kepentingan umum diidentikkan dengan kepentingan seluruh lapisan masyarakat, ${ }^{31}$ yang dilakukan dan selanjutnya dimiliki Pemerintah serta tidak digunakan untuk mencari keuntungan. Bentuk-bentuk kegiatan yang bersifat kepentingan umum meliputi 14 bidang kegiatan pembangunan. ${ }^{32}$

Pengadaan tanah merupakan wewenang Panitia Pengadaan Tanah yang dibentuk oleh Gubernur. ${ }^{33}$ Kegiatan pembangunan untuk kepentingan umum tersebut, harus sesuai dengan Rencana Umum Tata Ruang yang telah ditetapkan terlebih dahulu atau perencanaan ruang wilayah atau kota yang sudah ada. ${ }^{34}$ Pemohon pengadaan tanah hanya terbatas pada instansi pemerintah, sedangkan pengadaan tanah untuk kepentingan usaha swasta dilaksanakan melalui jual-beli, tukar menukar atau cara lain yang disepakati secara sukarela oleh pihak-pihak yang bersangkutan, ${ }^{35}$ sama dengan pengadaan tanah untuk kepentingan umum oleh instansi pemerintah yang luasnya tidak lebih dari 1 (satu) hektar. ${ }^{36}$

Berdasarkan kriteria kepentingan umum dalam Keppres No. 55 Tahun 1993 di atas, pengertian kepentingan umum, yang pengadaan tanahnya dilakukan pemerintah, diekspresikan melalui tiga cara: Pertama, dalam bentuk Pedoman Umum (General Guide) yang menyatakan bahwa kepentingan umum adalah kepentingan seluruh lapisan masyarakat, tetapi apakah yang dimaksud dengan kepentingan seluruh lapisan masyarakat tersebut tidak dijelaskan. Kedua, ketentuan-ketentuan daftar (list provisions) yang meliputi 14 (empat belas) bidang kegiatan pembangunan, dan Ketiga, ciri atau persyaratan bahwa kegiatan kepentingan umum tersebut, harus sesuai dengan Rencana Umum Tata Ruang yang telah ditetapkan sebelumnya,

\footnotetext{
${ }^{31}$ Pasal 1 Ayat (3) Keppres No. 55 Tahun 1993 tentang Pengadaan Tanah Bagi Pelaksanaan Pembangunan Untuk Kepentingan Umum.

${ }^{32}$ Pasal 5 Ayat (1) Keppres No. 55 Tahun 1993.

${ }^{33}$ Pasal 6 Ayat (1) Keppres No. 55 Tahun 1993.

${ }^{34}$ Pasal 4 Ayat (1) dan (2) Keppres No.55 Tahun 1993.

${ }^{35}$ Pasal 2 Ayat (2) dan (3) Keppres No. 55 Tahun 1993.

${ }^{36}$ Pasal 23 Keppres No. 55 Tahun 1993.
} 
dilakukan dan dimiliki oleh Pemerintah, dan tidak digunakan untuk mencari keuntungan.

Dalam Perpres No. 36 Tahun 2005, ${ }^{37}$ yang menggantikan Keppres No. 55 Tahun 1993, sebagaimana yang telah direvisi dengan Perpres No. 65 Tahun 2006,38 pengertian kepentingan umum dirumuskan sebagai kepentingan sebagian besar lapisan masyarakat. ${ }^{39}$ Pembangunan untuk kepentingan umum tersebut dilaksanakan oleh Pemerintah atau Pemerintah Daerah, dan selanjutnya dimiliki atau akan dimiliki oleh Pemerintah atau Pemerintah Daerah, yang meliputi 7 (tujuh) bidang kegiatan pembangunan. ${ }^{40}$

Pengadaan tanah untuk kepentingan umum tersebut, hanya dapat dilakukan apabila sesuai dengan Rencana Tata Ruang Wilayah yang telah ditetapkan lebih dahulu atau berdasarkan perencanaan ruang wilayah/kota yang sudah ada. ${ }^{41}$ Wewenang pengadaan tanah diberikan kepada Panitia Pengadaan Tanah Kabupaten/Kota yang dibentuk oleh Bupati/Walikota atau oleh Panitia Pengadaan Tanah Provinsi yang dibentuk oleh Gubernur untuk wilayah DKI atau apabila tanahnya berada di dua wilayah kabupaten/kota, atau oleh Panitia Pengadaan Tanah yang dibentuk oleh Menteri Dalam Negeri apabila tanahnya berada di dua wilayah provinsi atau lebih. ${ }^{42}$ Pengadaan tanah yang luasnya tidak lebih dari 1 (satu) hektar dapat dilakukan langsung oleh Instansi Pemerintah yang memerlukan tanah dengan para pemegang hak atas tanah, dengan cara jual-beli atau tukar menukar atau cara lain yang disepakati kedua belah pihak. ${ }^{43}$

Berdasarkan kriteria kepentingan umum dalam Keppres No. 36 Tahun 2005 di atas, pengertian kepentingan umum yang pengadaan tanahnya dilakukan oleh Pemerintah, diekspresikan melalui tiga cara: Pertama, dalam bentuk Pedoman Umum (General Guide) dengan menyatakan bahwa kepentingan umum identik dengan kepentingan sebagian lapisan masyarakat, tetapi apakah yang dimaksud dengan kepentingan sebagian lapisan masyarakat tersebut, tidak dijelaskan, Kedua, ketentuan-ketentuan daftar (list provisions) dengan menyebutkan bahwa kepentingan

\footnotetext{
${ }^{37}$ Perpres No.36 Tahun 2005 tentang Pengadaan Tanah Bagi Pelaksanaan Pemvangunan Untuk Kepentingan Umum.

${ }^{38}$ Perpres No.65 Tahun 2006 tentang Perubahan Atas Peraturan Presiden No.36 Tahun 2005 tentang Pengadaan Tanah Bagi Pelaksanaan Pembangunan Untuk Kepentingan Umum.

${ }^{39}$ Pasal 1 Angka 5 Perpres No.36 Tahun 2005.

${ }^{40}$ Pasal 5 Keppres No. 36 Tahun 2005, setelah diubah dengan Perpres No.65 Tahun 2006.

${ }^{41}$ Pasal 4 Ayat (1) dan (2) Perpres No. 36 Tahun 2005.

${ }^{42}$ Pasal 6 Ayat (1), (2),(3) dan (4) Perpres No.36 Tahun 2005 setelah diubah dengan Perpres No.65 Tahun 2006.

${ }^{43}$ Pasal 20 Keppres No.36 Tahun 2005.
} 
umum tersebut meliputi 7 (tujuh) bidang kegiatan, Ketiga, ciri atau persyaratan bahwa kegiatan kepentingan umum tersebut harus sesuai dengan Rencana Tata Ruang Wilayah, dilaksanakan oleh Pemerintah atau Pemerintah Daerah, dimiliki atau akan dimiliki oleh Pemerintah atau Pemerintah Daerah.

Mencermati kriteria kepentingan umum dalam peraturan perundanganundangan yang telah diuraikan di atas, ternyata tidak terdapat adanya pengertian yang baku tentang kepentingan umum. Peraturan perundang-undangan tidak memberikan penjelasan tentang pengertian kepentingan umum, dan membiarkannya dalam bentuk Pedoman Umum (General Guide). Namun sangat jelas bahwa secara filosofis, tujuan pengadaan tanah untuk kepentingan umum adalah untuk mewujudkan kesejahteraan umum yang berkeadilan. ${ }^{44}$ Karena itu pemaknaan sifat kepentingan umum tidak akan dapat dipahami jika diinterpretasi secara formal dan tekstual. Pemaknaan kepentingan umum harus dilihat secara substansial dan kontekstual.

Peraturan perundang-undangan hanya melengkapi pengertian kepentingan umum dengan menetapkan Ketentuan-Ketentuan Daftar (list provision), dengan menyebutkan sejumlah bidang kegiatan pembangunan yang mempunyai sifat kepentingan umum. ${ }^{45}$ Penetapan bidang-bidang kegiatan pembangunan tersebut, memang memberikan bentuknya yang konkrit, sehingga memudahkan untuk dilaksanakan.

Namun demikian, bentuk-bentuk kegiatan pembangunan itu lebih mementingkan wujud bangunan yang akan diletakkan di atas tanah yang diambil untuk kepentingan umum, sementara apakah bangunan tersebut benar-benar akan berfungsi untuk kepentingan umum, tetap menjadi persoalan.

Dalam praktik, oleh Panitia Pengadaan Tanah, kepentingan umum hanya dimaknai secara formal, sebatas peruntukkan, bahwa di atas tanah yang diambil oleh pemerintah dari pemiliknya akan dilakukan kegiatan kepentingan umum, tanpa melihat apakah kemudian di atas tanah yang telah diambil oleh pemerintah tersebut, benar-benar memberikan manfaat bagi kepentingan umum. ${ }^{46}$ Sementara masyarakat

\footnotetext{
${ }^{44}$ Penjelasan Umum angka II angka (4) UU No.5 Tahun 1960 tentang Peraturan Dasar Pokok-Pokok Agraria.

${ }^{45}$ Pasal 1 ayat (2) Inpres No. 9 Tahun 1973 tentang Pelaksanaan Pencabutan Hak-Hak Atas Tanah dan BendaBenda Yang Ada Di Atasnya, Pasal 5 Keppres No.55 Tahun 1993 tentang Pengadaan Tanah Bagi Pembangunan Untuk Kepentingan Umum, dan Pasal 5 Perpres No.65 Tahun 2006 tentang Perubahan Atas Perpres No.36 Tahun 2005 tentang Pengadaan Tanah Bagi Pembangunan Untuk Kepentingan Umum.

${ }^{46}$ Disimpulkan dari penuturan Drs.H.WN. Djangdjaya dan H. Kadir Hamid, Mantan Birokrat, Wawancara, Febuari 2010
} 
pemilik tanah memaknai kepentingan umum dari kemanfaatan konkrit tanah tersebut. ${ }^{47}$

Pada kasus pengadaan tanah untuk kepentingan umum berupa pembangunan Asrama TNI di Dusun Besar Kecamatan Talang IV Bengkulu Utara, misalnya, ternyata yang benar-benar langsung dipergunakan untuk pembangunan Asrama TNI hanya separuh dari luas lahan yang diambil, sedangkan separuhnya lagi menjadi terlantar dan kemudian dikuasai kembali oleh masyarakat. Setelah 23 (dua puluh tiga) tahun kemudian, ketika tanah tersebut sudah dikuasai oleh masyarakat, oleh TNI baru akan dibangun Lapangan Tembak, sehingga memunculkan sengketa baru. ${ }^{48}$

Demikian pula dengan pengadaan tanah bagi kepentingan usaha swasta untuk perkebunan besar, yang di masa lalu pengadaannya dilakukan oleh Pemerintah. Banyak lahan yang telah diambil dari masyarakat dan kemudian diberikan kepada Perusahaan dengan Hak Guna Usaha (HGU), tidak benar-benar diusahakan sehingga menjadi terlantar, seperti kasus penelantaran HGU di Kecamatan Ketahun Bengkulu Utara yang dilakukan oleh PT. Way Sebayur dan kasus penelantaran HGU di Desa Renah Kandis dan Desa Plajau Bengkulu Tengah oleh PT Bengkulu Sawit Jaya. ${ }^{49}$ Ini jelas bertentangan dengan tujuan kepentingan umum, karena tanah yang terlantar tidak akan memberi manfaat apapun bagi kesejahteraan masyarakat, sehingga bertentangan dengan tujuan diperbolehkannya menguasai tanah tersebut

Dalam sistem hukum adat setempat, jika pemilik tanah menelantarkan tanahnya, akan merugikan kepentingan seluruh persekutuan hukum yang bersangkutan. Tindakan menelantarkan tanah merupakan bentuk pelanggaran yang menyalahi tujuan..$^{50}$ Tanah yang ditelantarkan akan kembali dikuasai oleh hak ulayat, dan dapat dimanfaatkan oleh anggota persekutuan. ${ }^{51}$ Pandangan masyarakat hukum adat yang demikian, menjelaskan mengapa masyarakat lokal sering menduduki dan mengambil bidang-bidang tanah terlantar, yang dimiliki oleh Perusahaan atau Pemerintah, yang dulunya diperoleh melalui pengadaan tanah untuk kepentingan umum.

Dari uraian di atas, dapat disimpulkan bahwa aparat pelaksana pengadaan tanah untuk kepentingan umum, cenderung memaknai kepentingan umum secara

\footnotetext{
${ }^{47}$ Disimpulkan dari penuturan H. Ibrahim (pemilik tanah), wawancara Pribadi, Febuari 2010

${ }^{48}$ Usman Yasin. Ketua dan Aktivis LSM Lembak Kota Bengkulu, Wawancara Pribadi, 6 Januari 2010

${ }^{49}$ Ibid.

${ }^{50}$ Arie Sukanti Sumatri, Konsepsi Yang Mendasari Penyempurnaan Hukum Tanah Nasional, Pidato Pengukuhan Guru Besar Tetap Dalam Ilmu Hukum Agraria, Fakultas Hukum Universitas Indonesia, 17 September 2003, hlm. 25.

${ }^{51}$ Iman Sudiyat, Hukum Adat Sketsa Azas, Liberty, Yogyakarta, 1978, hlm. 17.
} 
formal, sehingga kepentingan umum hanya dipahami sebatas peruntukan tanah, dan tidak sampai pada manfaat yang benar-benar dihasilkan dari penggunaan tanah tersebut bagi kepentingan umum, sedangkan masyarakat memaknai kepentingan umum dari kemanfaatan konkrit tanah tersebut bagi masyarakat.

\section{Pemaknaan Pemilik Tanah dan Aparat Pelaksana Pengadaan Tanah tentang Kepemilikan Tanah}

Kepemilikan tanah masyarakat adat, berangkat dari pandangan religius yang menganggap tanah sebagai bagian dari alam semesta ciptaan Ilahi untuk kepentingan makhluknya. Manusia sebagai salah satu bagian dari makhluk berupaya mencari apa yang menjadi kebutuhannya, memanfaatkan apa yang diperoleh dan menggali terus sumber daya alam yang lebih baru dan lebih banyak dibanding kehidupan masa sebelumnya. Karena lahan pertanahan saat itu tak terukur luasnya, tidak jelas subyek dan batasnya, maka tanah hanya dapat dikuasai secara ipso facto. Artinya tanah dipandang dikuasai apabila secara kasat inderawi telah nyata-nyata ditempati, dimanfaatkan, diusahakan dan dirawat oleh seseorang, baik sebagai pemukim maupun penggarapnya. ${ }^{52}$ Ini berbeda dengan konsep Barat, yang mendalilkan kepemilikan tanah secara ipso jure, yaitu berdasarkan pembenaran yuridis ${ }^{53}$ yang harus dibuktikan secara formal dengan Sertifikat.

Cara perolehan hak atas tanah dalam masyarakat hukum adat yang demikian, sejalan dengan teori Occupation maupun teori kerja perorangan. Hak milik perorangan adalah hak milik individual, yang asal muasalnya merupakan hak buka pertama. ${ }^{54}$ Ini juga sejalan dengan pandangan J.J. Rosseau yang mengatakan bahwa dalam menentukan hak atas tanah penting dipertimbangkan siapa yang menempati pertama kalinya. ${ }^{55}$

Hak milik pada asasnya tidak boleh diganggu, akan tetapi negara mempunyai wewenang untuk mencabut hak privat dari seseorang berlawanan dengan kemauannya, untuk kepentingan umum atau hak itu diberikan kepada pihak lain. ${ }^{56}$ Duguit mengemukakan bahwa pemilik tidak bisa menggunakan secara sewenang-wenang,

\footnotetext{
${ }^{52}$ Soetandyo Wignyosoebroto, Tanah Negara, Tanah Adat yang Dinasionalisasi, Elsam, Jakarta, 1996.

${ }^{53}$ Muslimin, Aspek-Aspek Hukum Otonomi Daerah, Alumni, Bandung, 2006, hlm. 14

${ }^{54}$ Putri Agus Wijayati, Tanah dan Sistem Perpajakan Masa Kolonial Inggris, Terawang, Yogyakarta, 2000, hlm.25.

${ }^{55}$ Jawahir Thontowi, Penguasaan dan Pemilikan Tanah Yang Diskriminatif : Hukum Internasional dan Hukum Nasional, Jurnal Hukum Ius Quia Iustum No.13 Vol 7, UII Yogyakarta, 2000, hlm. 32

${ }^{56}$ R. Roestandi Ardiwilaga, Hukum Agraria Dalam Teori dan Praktek, Masa Baru, Jakarta, 1962, hlm. 275.
} 
tetapi harus menggunakan hak milik tersebut berfungsi sosial (social function). ${ }^{57}$ Dengan demikian hak milik tidak bersifat absolut, melainkan dibatasi oleh fungsi sosialnya dan demi kepentingan umum hak tersebut dapat dicabut oleh negara.

Pandangan di atas sejalan dengan konsep pengadaan tanah untuk kepentingan umum di Indonesia, yang didasarkan pada Hak Menguasai Negara (HMN) atas tanah, yaitu untuk sebesar-besarnya kemakmuran rakyat. ${ }^{58}$ Maka semua hak atas tanah mempunyai fungsi sosial. ${ }^{59}$

Konsep fungsi sosial hak atas tanah dalam UUPA, dikembangkan dari konsep hukum adat. Tanah tidak boleh ditelantarkan, karena akan merugikan kepentingan seluruh masyarakat dalam persekutuan hukum yang bersangkutan. Jika tanah ditelantarkan, maka tindakan itu merupakan bentuk pelanggaran yang menyalahi tujuan diperbolehkannya menguasai tanah, ${ }^{60}$ karena itu, dalam jangka tertentu, tanah yang terlantar akan kembali menjadi tanah hak ulayat persekutuan masyarakat hukum yang bersangkutan, dan dapat diusahakan oleh perorangan di antara anggota persekutuan masyarakat hukum yang bersangkutan. Tanah-tanah yang sudah berada dalam pengusahaan perorangan diakui oleh masyarakat sebagai hak orang yang bersangkutan dan orang lain tidak boleh mengganggu tanah tersebut. Dengan demikian, maka objek hak ulayat atas tanah sesungguhnya adalah bidang-bidang tanah yang belum dipunyai oleh perorangan. ${ }^{61}$

UUPA menjadikan hubungan hak ulayat pada persekutuan masyarakat hukum adat yang demikian itu, sebagai acuan untuk menentukan hubungan antara bangsa Indonesia dengan tanah. Hubungan bangsa Indonesia dengan tanah merupakan hubungan hak ulayat yang diangkat pada tingkatan yang mengenai seluruh wilayah negara. ${ }^{62}$ Kemudian guna mengatur hubungan bangsa Indonesia dengan tanah, lebih lanjut ditegaskan bahwa pada tingkatan yang tertinggi tanah dikuasai oleh negara. Penguasaan negara atas tanah yang dimaksudkan itu, meliputi semua tanah, termasuk bidang-bidang tanah yang telah dihaki oleh seseorang Namun demikian kekuasaan negara atas tanah yang sudah dipunyai orang dengan suatu hak, dibatasi oleh isi dari hak yang dimiliki orang tersebut, dan karena itu negara hanya dapat

\footnotetext{
${ }^{57}$ G.W. Paton, A Texbook of Jurisprudence, fourth edition, Oxford University Press, 1972, hlm. 541.

${ }^{58}$ Pasal 33 ayat (3) UUD NRI 1945.

${ }^{59}$ Pasal 6 Undang-Undang No.5 Tahun 1960.

${ }^{60}$ Arie Sukanti Sumantri, Konsepsiyang Mendasari Penyempurnaan Hukum Tanah Nasional, 2003, hlm. 25, Pidato Pengukuhan Guru Besar dalam Ilmu Hukum Agraria Fakultas Hukum UI.

${ }^{61}$ Muhammad Bakri, Op.Cit, hlm. 111.

${ }^{62}$ Penjelasan Umum angka II butir (1) UU No.5 Tahun 1960 tentang Peraturan Dasar Pokok-Pokok Agraria.
} 
memberikan tanah kepada seseorang atau badan hukum, terbatas pada bidang tanah yang tidak dipunyai oleh seseorang atau pihak lain. ${ }^{63}$

Tanah milik perorangan dan tanah hak ulayat, diakui keberadaannya dan dilindungi oleh negara. Namun, karena semua hak atas tanah dikonsepsikan mempunyai fungsi sosial, maka penggunaannya tidak dapat semata-mata untuk kepentingan pribadi pemiliknya. Penggunaan tanah harus disesuaikan dengan keadaannya dan sifat dari haknya, sehingga bermanfaat bagi kesejahteraan dan kebahagiaan yang mempunyainya maupun bagi masyarakat dan negara. ${ }^{64}$ Dengan demikian, fungsi sosial hak atas tanah, sama sekali tidak dimaksudkan untuk mengurangi kesejahteraan dan kebahagiaan pemilik hak atas tanah yang bersangkutan.

Berdasarkan konsepsi UUPA yang dikemukakan di atas, maka dapat disimpulkan bahwa dalam pengadaan tanah untuk kepentingan umum, sebagai salah satu perwujudan fungsi sosial tanah, hak perseorangan, termasuk hak ulayat masyarakat hukum adat, tetap diakui dan dilindungi. Pengambilan bidang-bidang tanah hak untuk kepentingan umum hanya dapat dilakukan dengan pemberian ganti kerugian yang layak. ${ }^{65}$

Persoalannya adalah pemilikan hak atas tanah yang diakui dan dilindungi tersebut masih menimbulkan perbedaan pendapat, terutama disebabkan oleh sikap UUPA berkaitan dengan hukum adat. Pada satu sisi UUPA menyatakan bahwa hukum agraria yang berlaku atas bumi, air dan ruang angkasa adalah hukum adat, tetapi pada sisi lain mengingkari hukum adat tersebut apabila bertentangan dengan kepentingan nasional dan negara, yang berdasarkan atas persatuan bangsa, dengan sosialisme Indonesia serta dengan peraturan-peraturan yang tercantum dalam UUPA dan peraturan perundang-undangan lainnya. ${ }^{66}$ Dengan demikian, keberlakuan hukum adat masih harus diuji dengan kepentingan nasional dan negara serta dengan seluruh perangkat peraturan perundang-undangan lainnya, yang apabila bertentangan, maka pemilikan tanah berdasarkan hukum adat tersebut menjadi tidak diakui dan karena itu tidak dilindungi.

Dalam kasus sengketa pengadaan tanah untuk kepentingan pembangunan Asrama TNI di Desa Dusun Besar, Marga Proatin XII Kecamatan Talang IV, terlihat

\footnotetext{
${ }^{63}$ Penjelasan Umum angka II butir (2) UU No.5 Tahun 1960

${ }^{64}$ Penjelasan Umum angka II butir (4) UU No.5 Tahun 1960

${ }^{65}$ Pasal 18 UU No.5 Tahun 1960 tentang Peraturan Dasar Pokok-Pokok Agraria.

${ }^{66}$ Pasal 5 UU No. 5 Tahun 1960
} 
bahwa dalam praktik pengadaan tanah untuk kepentingan umum kepemilikan tanah berdasarkan hukum adat telah diingkari. ${ }^{67}$ Aparat pelaksana pengadaan tanah berpandangan bahwa tanah tersebut dianggap masih berstatus sebagai tanah Marga (hak ulayat), sedang penguasaan mereka atas tanah itu dilakukan secara tidak sah, karena tidak dapat menunjukkan surat bukti pemilikan. ${ }^{68}$

Pengingkaran terhadap hak atas tanah berdasarkan hukum adat, juga terjadi dalam pengadaan tanah untuk perkebunan sawit PT. Bio Nusantara Teknologi di Desa Padang Betuah Kecamatan Pondok Kelapa Bengkul Utara. ${ }^{69}$ Pada kasus ini, pengingkaran terhadap hak atas tanah yang diperoleh warga berdasarkan hukum adat, disebabkan karena Pemerintah berpandangan hak atas tanah tersebut belum terdaftar. ${ }^{70}$

Uraian di atas, menunjukkan adanya perbedaan pemaknaan terhadap hak atas tanah antara aparat pelaksana pengadaan tanah dengan pemilik tanah. Panitia pengadaan tanah memaknai hak atas tanah berdasarkan sudut pandang legal-formal menurut peraturan perundang-undangan, yang mengakui pemilikan tanah secara ipso-jure. Sedangkan masyarakat pemilik tanah adat memberikan makna terhadap kepemilikan hak atas tanahnya dari sudut pandang menurut hukum adat, yang mengakui pemilikan tanah secara ipso facto.

\section{Pemaknaan Pemilik Tanah dan Aparat Pengadaan Tanah Tentang Ganti Kerugian Yang Layak}

Pengadaan tanah untuk kepentingan umum, baik melalui pencabutan maupun melalui musyawarah, diwajibkan untuk memberikan ganti kerugian yang layak. Ganti kerugian yang layak itu sesungguhnya berada dalam bentuk rasa kepatutan, yang tidak dapat diatur secara pasti dalam peraturan perundang-undangan.

Dalam pengadaan tanah untuk kepentingan umum melalui pencabutan hak, ganti kerugian yang layak itu didasarkan atas nilai nyata/sebenarnya dari tanah atau benda yang bersangkutan. Harga yang didasarkan atas nilai yang nyata/ sebenarnya itu tidak mesti sama dengan harga umum, karena harga umum bisa

\footnotetext{
${ }^{67}$ H. Ibrahim, Dusun Besar Kecamatan Gading Cempaka Kota Bengkulu, Wawancara Pribadi 15 Desember 2009

${ }^{68}$ Dokumen Putusan Pengadilan Negeri Bengkulu No.12/1978/Bkl, hlm 5

${ }^{69}$ Siham, Wawancara Pribadi, Desa Padang Betuah Kecamatan Pondok Kelapa Bengkulu Utara, Febuari 2010

${ }^{70}$ Keputusan Kepala Badan Pertanahan Nasional No.23/HGU/BPN/90 tentang Pemberian Hak Guna Usaha Atas Nama PT. Bio Nusantara Teknologi Bengkulu, Bagian Menimbang, huruf a.
} 
merupakan harga "catut". Tetapi sebaliknya, harga tersebut tidak pula berarti harga yang murah.

Ganti kerugian bukan hanya terhadap orang-orang yang berhak atas tanah tetapi juga orang-orang yang menempati rumah atau menggarap tanah yang bersangkutan, dengan memberikan ganti tempat tinggal atau tanah garapan lainnya, atau ganti kerugian berupa uang atau fasilitas-fasilitas tertentu, misalnya transmigrasi. ${ }^{71}$

Besarnya ganti kerugian dalam pencabutan hak ditetapkan oleh Presiden, berdasarkan taksiran ganti kerugian yang dilakukan oleh Panitia Penaksir, dengan tidak merugikan kedua belah pihak dan dengan menggunakan norma-norma serta memperhatikan harga-harga penjualan tanah/bangunan/tanaman di sekitarya yang terjadi dalam tahun yang sedang berjalan, dengan tetap memperhatikan pedomanpedoman yang ada dan lazim dipergunakan dalam mengadakan penaksiran harga/ ganti rugi atas tanah/bangunan yang berlaku dalam daerah yang bersangkutan. ${ }^{72}$

Dalam hal akan dilakukan penampungan orang-orang yang hak atas tanahnya dicabut, maka yang berkepentingan harus mengusahakan sedemikian rupa agar mereka yang dipindahkan itu tetap dapat menjalankan kegiatan usahanya / mencari nafkah kehidupan yang layak seperti semula. ${ }^{73}$ Dengan ganti kerugian yang layak tersebut, pemilik/pemegang hak atas tanah itu tidak mengalami kemunduran baik dalam bidang sosial maupun pada tingkat ekonominya. ${ }^{74}$

Pengertian ganti kerugian yang layak dalam pengadaan tanah melalui pencabutan hak, memberikan batasan penting bahwa ganti kerugian yang dibayarkan oleh Pemerintah, tidak boleh merugikan pemilik tanah, tanaman atau bangunan. Penaksiran besarnya ganti kerugian, dilakukan dengan memperhatikan harga pasar, yaitu harga-harga penjualan tanah, bangunan atau tanaman disekitarnya, yang terjadi dalam tahun yang sedang berjalan.

Pengadaan tanah untuk kepentingan umum melalui pencabutan hak, dalam praktik jarang dilakukan, karena pengadaan tanah untuk kepentingan umum sangat menekankan agar dilakukan dengan persetujuan yang empunya. Pencabutan hak

\footnotetext{
${ }^{71}$ Penjelasan Umum angka (5) UU No. 20 Tahun 1961 tentang Pencabutan Hak-Hak Atas Tanah Dan BendaBenda Yang Ada Di Atasnya.

${ }^{72}$ Pasal 5 Ayat (1) dan (2) Inpres No.9 Tahun 1973 tentang Pedoman-Pedoman Pelaksanaan Pencabutan HakHak Atas Tanah Dan Benda-Benda Yang Ada Di Atasnya.

${ }^{73}$ Pasal 6 Ayat (2) Inpres No. 9 Tahun 1973. tentang Pedoman-Pedoman Pelaksanaan Pencabutan Hak-Hak Atas Tanah Dan Benda-Benda Yang Ada Di Atasnya.

${ }^{74}$ Penjelasan Umum PP No.39 Tahun 1973 tentang Acara Penetapan Ganti Kerugian Oleh Pengadilan Tinggi Sehubungan Dengan Pencabutan Hak-Hak Atas Tanah Dan Benda-Benda Yang Ada Di Atasnya.
} 
hanya dilakukan dalam keadaan yang memaksa, yaitu jika jalan musyawarah tidak dapat membawa hasil yang diharapkan, karena yang empunya meminta harga yang terlalu tinggi atau tidak bersedia sama sekali untuk melepaskan tanahnya yang diperlukan tersebut. ${ }^{75}$

Dalam pengadaan tanah melalui musyawarah, dalam apa yang disebut dengan Pembebasan tanah, besarnya ganti kerugian ditetapkan oleh Panitia Pembebasan Tanah yang dibentuk oleh Gubernur. ${ }^{76}$ Dalam menetapkan besarnya ganti kerugian tersebut, Panitia Pembebasan Tanah harus mengadakan musyawarah dengan para pemegang hak atas tanah, bangunan dan tanaman, berdasarkan harga umum setempat; dengan memperhatikan lokasi dan faktor-faktor strategis lainnya yang dapat mempengaruhi harga tanah. ${ }^{77}$

Harga umum setempat adalah harga dasar yang ditetapkan secara berkala oleh suatu Panitia untuk sesuatu daerah menurut jenis penggunaan tanahnya. ${ }^{78}$ Ganti rugi atas bangunan dan tanaman, harus berpedoman pada ketentuan yang telah ditetapkan oleh Dinas Pekerjaan Umum/Dinas Pertanian setempat. ${ }^{79}$

Khusus untuk pengadaan tanah yang luasnya tidak lebih dari 5 (lima) hektar, pengadaannya dilakukan langsung oleh Pemimpin Proyek instansi pemerintah yang bersangkutan, ${ }^{80}$ dan besarnya ganti rugi ditentukan berdasarkan kesepakatan dengan pemilik/pemegang hak atas tanah yang bersangkutan, dengan tetap memperhatikan ketentuan harga dasar yang ditetapkan oleh Kepala Daerah. ${ }^{81}$ Apabila tidak tercapai kesepakatan, maka Pemimpin Proyek segera mencari lokasi lain untuk penggantinya. ${ }^{82}$

Pengertian ganti kerugian yang layak dalam pengadaan tanah untuk kepentingan umum melalui pembebasan tanah, pada dasarnya ditentukan oleh kata sepakat antara Panitia Pembebasan Tanah/Pemimpin Proyek dengan pemilik tanah, bangunan atau tanaman. Artinya ganti kerugian adalah layak apabila disetujui secara sukarela oleh pemilik tanah, bangunan dan tanaman.

\footnotetext{
${ }^{75}$ Penjelasan Umum angka (2) UU No.20 Tahun 1961.

${ }^{76}$ Pasal 1 angka (2) Permendagri No.15 Tahun 1975 tentang Ketentuan-Ketentuan Mengenai Tata Cara Pembebasan Tanah.

${ }^{77}$ Pasal 6 Ayat (1) dan (2) huruf a Permendagri No.15 Tahun 1975 tentang Ketentuan-Ketentuan Tentang Tata Cara Pembebasan Tanah

${ }^{78}$ Pasal 1 angka (4) Permendagri No.15 Tahun 1975

${ }^{79}$ Pasal 6 Ayat (2) huruf a Permendagri No.15 Tahun 1975 tentang Ketentuan-Ketentuan Tentang Tata Cara Pembebasan Tanah

${ }^{80}$ Pasal 2 Ayat (1) dan (2) Permendagri No.2 Tahun 1985 tentang Tata Cara Pengadaan Tanah Untuk Keperluan Proyek Pembangunan Di Wilayah Kecamatan.

${ }^{81}$ Pasal 5 Ayat (1) dan (2) Permendagri No.2 Tahun 1985

${ }^{82}$ Pasal 7 Ayat (2) Permendagri No.2 Tahun 1985
} 
Pada pengadaan tanah untuk kepentingan umum melalui musyawarah, dalam apa yang disebut dengan Pelepasan atau Penyerahan Hak, ${ }^{83}$ bentuk ganti kerugian dapat berupa uang, tanah pengganti, pemukiman kembali, gabungan dari dua atau lebih (berupa uang, tanah pengganti dan atau pemukiman kembali) serta bentuk lain yang disetujui oleh pihak-pihak yang bersangkutan. ${ }^{84}$ Dasar dan cara penghitungan ganti kerugian terhadap tanah didasarkan atas nilai nyata atau sebenarnya, dengan memperhatikan nilai jual objek pajak (NJOP) yang terakhir, sedangkan ganti kerugian atas bangunan ditaksir oleh instansi Pemerintah Daerah yang bertanggungjawab di bidang bangunan, dan ganti kerugian atas tanaman ditaksir oleh instansi Pemerintah Daerah yang bertanggungjawab di bidang pertanian..$^{85}$

Panitia Pengadaan Tanah mengeluarkan keputusan mengenai bentuk dan besarnya ganti kerugian sesuai dengan kesepakatan yang dicapai oleh pemegang hak atas tanah dan instansi Pemerintah yang memerlukan tanah. ${ }^{86}$ Namun apabila musyawarah telah dilakukan berulangkali, kesepakatan mengenai bentuk dan besarnya ganti kerugian tidak juga tercapai, maka Panitia Pengadaan Tanah mengeluarkan keputusan mengenai bentuk dan besarnya ganti kerugian tersebut, dengan memperhatikan pendapat dan keinginan, saran dan pertimbangan yang berlangsung dalam musyawarah. ${ }^{87}$

Khusus dalam pengadaan tanah untuk kepentingan umum yang luasnya tidak lebih dari 1 (satu) hektar dapat dilakukan langsung oleh instansi Pemerintah yang memerlukan tanah dengan para pemegang hak atas tanah, dengan cara jual-beli atau tukar menukar atau cara lain yang disepakati kedua belah pihak..$^{88}$

Dalam perkembangannya yang terakhir ${ }^{89}$ pengertian ganti kerugian yang layak adalah yang dapat memberikan kelangsungan hidup yang lebih baik bagi pemilik tanah dari tingkat kehidupan sosial ekonomi sebelum terkena pengadaan tanah.90

\footnotetext{
${ }^{83}$ Sebagaimana yang diatur dalam Kepres No.55 Tahun 1993 yang kemudian digantikan dengan Perpres No.36 Tahun 2005 dan kemudian diubah dengan Perpres No.65 Tahun 2006

${ }^{84}$ Pasal 13 Kepres No. 55 Tahun 1993

${ }^{85}$ Pasal 15 Kepres No.55 Tahun 1993

${ }^{86}$ Pasal 8 Kepres No.55 Tahun 1993

${ }^{87}$ Pasal 18 dan 19 Kepres No.55 Tahun 1993

${ }^{88}$ Pasal 23 Kepres No. 55 Tahun 1993

${ }^{89}$ Kepres No.55 Tahun 1993 dicabut dan digantikan dengan Perpres No.36 Tahun 2005 kemudian diubah dengan Perpres No.65 Tahun 2006.

${ }^{90}$ Pasal 1 angka 11 Perpres No.36 Tahun 2005 tentang Pengadaan Tanah Bagi Pelaksanaan Pembangunan Untuk Kepentingan Umum
} 
Bentuk dan besarnya ganti kerugian ditetapkan oleh Panitia Pengadaan Tanah, sesuai dengan kesepakatan antara pemegang hak atas tanah dengan instansi Pemerintah dan/atau Pemerintah Daerah yang memerlukan tanah. ${ }^{91}$ Apabila musyawarah tidak dapat menghasilkan kesepakatan, dan upaya musyawarah telah berlangsung selama 120 hari terhitung sejak tanggal undangan musyawarah pertama, sedangkan kegiatan pembangunan untuk kepentingan umum tersebut secara teknis tata ruang tidak dapat dipindahkan ke tempat atau lokasi lain, maka Panitia Pengadaan Tanah menetapkan sendiri bentuk dan ganti kerugian tersebut dan menitipkan ganti rugi uang kepada pengadilan negeri yang wilayah hukumnya meliputi lokasi tanah yang bersangkutan. ${ }^{22}$

Dasar perhitungan ganti rugi terhadap tanah didasarkan atas NJOP atau nilai nyata/sebenarnya dengan memperhatikan NJOP tahun berjalan sesuai penilaian Lembaga/Tim Penilai Harga Tanah yang ditunjuk oleh panitia. Nilai jual bangunan ditaksir oleh perangkat daerah yang bertanggungjawab di bidang bangunan, dan nilai jual tanaman ditaksir oleh perangkat daerah yang bertanggungjawab di bidang pertanian..$^{93}$ Lembaga/Tim Penilai Harga Tanah ditetapkan oleh Bupati/Walikota atau oleh Gubernur bagi Provinsi Daerah Khusus Ibukota Jakarta. ${ }^{94}$

Khusus pengadaan tanah skala kecil, yang luasnya tidak lebih dari 1 (satu) hektar, dapat dilakukan langsung oleh instansi pemerintah yang memerlukan tanah dengan para pemegang hak atas tanah, melalui jual-beli atau tukar menukar atau cara lain yang disepakati kedua belah pihak. ${ }^{95}$

Pengertian ganti kerugian yang layak dalam pengadaan tanah yang dilakukan melalui pelepasan atau penyerahan hak, diberikan tekanan pada dua hal, yaitu pertama, besarnya ganti kerugian yang layak pada dasarnya ditentukan oleh kata sepakat antara instansi pemerintah yang memerlukan tanah dengan para pemilik tanah, bangunan dan tanaman; kedua, ganti keugian yang layak tersebut harus dapat memberikan kelangsungan hidup yang lebih baik dari tingkat kehidupan sosial ekonomi sebelum terkena pengadaan tanah.

Akan tetapi di dalam praktik, seperti yang terlihat dalam kasus sengketa pengadaan tanah untuk pembangunan asrama TNI di Dusun Besar Kecamatan

\footnotetext{
${ }^{91}$ Pasal 11 Perpres No.36 Tahun 2005

${ }^{92}$ Pasal 10 Perpres No. 36 Tahun 2005 tentang Pengadaan Tanah Bagi Pembangunan Untuk Kepentingan Umum.

${ }^{93}$ Pasal 15 Perpres No.65 Tahun 2006 tentang Perubahan Atas Perpres No.36 Tahun 2005 tentang Pengadaan Tanah Bagi Pembangunan Untuk Kepentingan Umum

${ }^{94}$ Pasal 15 Perpres No. 36 Tahun 2005

${ }^{95}$ Pasal 20 Perpres No.36 Tahun 2005
} 
Talang IV Bengkulu Utara, besarnya ganti kerugian ditolak oleh pemegang hak atas tanah dan tanaman karena dua alasan, yaitu: pertama, penentuan besarnya ganti kerugian oleh Panitia Pembebasan Tanah, tanpa melalui musyawarah dengan pemilk tanah/bangunan/tanaman, kedua besarnya ganti kerugian dinilai tidak layak karena jumlahnya tidak memungkinkan bagi mereka untuk membangun kembali usaha yang serupa di tempat lain..$^{96}$

Penolakan dengan alasan serupa, juga terjadi pada kasus sengketa pengadaan tanah untuk perkebunan sawit PT. Bio Nusantara Teknologi di Desa Padang Betuah Kecamatan Pondok Kelapa Bengkulu Utara. Pemilik tanah dan tanaman perkebunan tersebut, menolak ganti kerugian yang disediakan, karena jumlah ganti kerugian yang disediakan tidak mencukupi untuk membuat kebun baru sebagai penggantinya. ${ }^{97}$

Demikian juga dalam sengketa pengadaan tanah di Desa Pagar Dewa Kecamatan Selebar Kota Bengkulu untuk pembangunan Pasar Pagar Dewa. Pemilik tanah, bangunan dan tanaman, juga "menolak" tanah pengganti yang disediakan oleh Pemda Kota Bengkulu, karena luas tanah pengganti, dikurangi 40 \% dengan alasan sebagai Sumbangan Wajib Tanah Untuk Pembangunan (SWTP), sesuai ketentuan yang ditetapkan oleh Walikota. Penolakan dilakukannya, dengan cara tidak memenuhi persyaratan administrasi penggantian tanah pada Kantor Badan Pertanahan Nasional Kota Bengkulu. ${ }^{98}$

Berdasarkan kasus di atas, tampak adanya perbedaan pemaknaan tentang ganti kerugian yang layak. Instansi pemerintah yang memerlukan tanah, termasuk Panitia Pengadaan Tanah, memaknai ganti kerugian yang layak secara formal berdasarkan ketentuan Perundang-undangan yang telah ditetapkan oleh Pemerintah, sementara para pemegang hak atas tanah memaknai ganti kerugian yang layak berdasarkan kebutuhannya untuk memperoleh kembali tanah, bangunan dan tanaman di tempat lain disekitarnya, sehingga dengan sendirinya mereka merujuk kepada harga pasar (harga yang hidup dalam masyarakat).

${ }^{96}$ H. Ibrahim, Dusun Besar Kecamatan Talang IV Bengkulu Utara (sekarang menjadi Kec. Gading Cempaka Kota Bengkulu), Wawancara Pribadi, Desember 2009.

${ }^{97}$ Siham, Pemilik Tanah yang terkena pembebasan Untuk Lahan Perkebunan Sawit PT. Bio Nusantara Teknologi di Desa Padang Betuah Kecamatan Pondok Kelapa Bengkulu Utara, Wawancara Pribadi, 1 Febuari 2010

${ }^{98}$ Sopar Marpaung, Pemilik Tanah yang terkena Pembebasan Untuk Pembangunan Pasar Pagar Dewa Kecamatan Selebar Kota Bengkulu, Wawancara Pribadi, 9 Febuari 2010 


\section{Penutup}

Berdasarkan keseluruhan uraian di atas, maka dapat disimpulkan bahwa sengketa dalam pengadaan tanah untuk kepentingan umum, disebabkan karena adanya perbedaan (gap) pemaknaan tentang hukum antara pemilik tanah dengan aparat pelaksana pengadaan tanah. Aparat pelaksana memaknai hukum dalam bentuknya sebagai peraturan perundang-undangan dan yang dipahami secara formaltekstual, sementara pemilik tanah memaknai hukum sebagai tradisi dan nilai-nilai yang hidup dalam masyarakat, yaitu: (1) aparat pelaksana pengadaan tanah memaknai kepentingan umum secara formal, yang dipahami sebatas peruntukan tanah, dan tidak sampai pada manfaat yang benar-benar dihasilkan dari penggunaan tanah tersebut bagi kepentingan umum, sedangkan pemilik tanah memaknai kepentingan umum dari kemanfaatan konkrit tanah tersebut bagi masyarakat. (2) aparat pelaksana pengadaan tanah untuk kepentingan umum memaknai hak milik atas tanah secara ipso jure berdasarkan peraturan perundang-undangan, sementara Pemilik tanah memaknai hak milik atas tanah secara ipso facto berdasarkan hukum adat. (3) aparat pelaksana pengadaan tanah memaknai harga ganti kerugian yang layak secara formal berdasarkan peraturan perundang-undangan, sementara pemilik tanah memaknai harga ganti kerugian yang layak secara substantif berdasarkan harga yang hidup dalam masyarakat (harga pasar).

Guna mencegah atau meminimalisir sengketa, ke depan, budaya hukum aparat pelaksana pengadaan tanah, perlu diubah dari tradisi legal positivism hukum menjadi progresif, agar lebih berkesesuaian dengan budaya hukum masyarakat pemilik tanah.

\section{Daftar Pustaka}

Agus Wijayati, Putri, Tanah dan Sistem Perpajakan Masa Kolonial Inggris, Terawang, Yogyakarta, 2000.

Aldila, M. Hendra, dkk., "Kewenangan Negara dalam Pencabutan Hak Atas Tanah demi Pembangunan Kepentingan Umum", Jurnal Bencoolen Justice, Vol. 2 No.1 April 2012.

Ardiwilaga, R. Roestandi, Hukum Agraria dalam Teori dan Praktek, Masa Baru, Jakarta, 1962.

Badan Pertanahan Nasional RI, REFORMA AGRARIA Mandat Politik, Konstitusi dan Hukum Dalam Rangka Mewujudkan Tanah untuk Keadilan dan Kesejahteraan Rakyat, 2007. 
Bakri, Muhammad, Hak Menguasai Tanah Oleh Negara, Paradigma Baru untuk Reformasi Agraria, Citra Media, Yogyakarta, 2007.

Damanik, Jayadi, Pembaruan Agraria dan Hak Asasi Petani, Lapera Pustaka, Yogyakarta, 2002.

Ginting, Darwin, “Reformasi Hukum Tanah dalam Rangka Perlindungan Hak Atas Tanah Perorangan dan Penanaman Modal dalam Bidang Agro Bisnis", Jurnal Hukum Ius Quia Iustum, Vol.18 No. 1, Januari 2011.

Muslimin, Aspek-Aspek Hukum Otonomi Daerah, Alumni, Bandung, 2006.

Notonagoro, Pancasila Falsafah Negara, Penerbit Airlangga, Surabaya, 1961.

Paton, G.W., A Texbook of Jurisprudence, fourth edition, Oxford University Press, 1972.

Rahardjo, Satjipto, Membedah Hukum Progresif, PT Kompas Media Nusantara, Jakarta, 2006.

Schmid, Von, Ahli Pemikir Besar Negara dan Hukum, Pembangunan, Jakarta, 1954.

Sitorus, Oloan dan Limbong, Dayat, Pengadaan Tanah Untuk Kepentingan Umum, Cetakan Pertama, Mitra Kebijakan Tanah Indonesia, Yogyakarta, 2004.

Sudiyat, Iman, Hukum Adat Sketsa Azas, Liberty, Yogyakarta, 1978.

Sufriadi, Yanto, "Penyebab Sengketa Pengadaan Tanah Untuk Kepentingan Umum (Studi Kasus Sengketa Pengadaan Tanah Untuk Kepentingan Umum di Bengkulu)", Jurnal Hukum Ius Quia Iustum, Vol.18 No. 1, Januari, 2011.

Sumardjono, Maria S.W, Tanah dalam Perspektif Hak Ekonomi Sosial dan Budaya, Penerbit Buku Kompas, Jakarta, 2009.

Sukanti Sumatri, Arie, Konsepsi yang Mendasari Penyempurnaan Hukum Tanah Nasional, Pidato Pengukuhan Guru Besar Tetap dalam Ilmu Hukum Agraria, Fakultas Hukum Universitas Indonesia, 17 September 2003.

Thontowi, Jawahir, "Penguasaan dan Pemilikan Tanah Yang Diskriminatif: Hukum Internasional dan Hukum Nasional", Jurnal Hukum Ius Quia Iustum Vol. 7 No.13, Yogyakarta, 2000.

Wignyosoebroto, Soetandyo, Tanah Negara, Tanah Adat yang Dinasionalisasi, Elsam, Jakarta, 1996.

Wawancara dengan Drs.H.WN. Djangdjaya dan H. Kadir Hamid, Mantan Birokrat.

Wawancara dengan Usman Yasin, Ketua dan Aktivis LSM Lembak Kota Bengkulu.

Wawancara dengan H. Ibrahim (pemilik tanah), warga Dusun Besar Kecamatan Gading Cempaka Kota Bengkulu.

Wawancara dengan Siham (pemilik tanah), warga Desa Padang Betuah Kecamatan Pondok Kelapa Bengkulu Utara.

Sopar Marpaung, pemilik tanah yang terkena Pembebasan untuk Pembangunan Pasar Pagar Dewa Kecamatan Selebar Kota Bengkulu. 
UU No. 5 Tahun 1960 tentang Peraturan Dasar Pokok-Pokok Agraria.

UU No. 20 Tahun 1961 tentang Pencabutan Hak-Hak Atas Tanah dan Benda-Benda yang Ada Di Atasnya.

Keppres No. 55 Tahun 1993 tentang Pengadaan Tanah Bagi Pelaksanaan Pembangunan Untuk Kepentingan Umum.

Perpres No.36 Tahun 2005 tentang Pengadaan Tanah Bagi Pelaksanaan Pembangunan Untuk Kepentingan Umum.

Perpres No.65 Tahun 2006 tentang Perubahan Atas Peraturan Presiden No.36 Tahun 2005 tentang Pengadaan Tanah Bagi Pelaksanaan Pembangunan Untuk Kepentingan Umum.

Inpres No.9 Tahun 1973 tentang Pedoman-Pedoman Pelaksanaan Pencabutan HakHak Atas Tanah dan Benda-Benda Yang Ada Di Atasnya.

Permendagri No.15 Tahun 1975 tentang Ketentuan-Ketentuan Mengenai Tata Cara Pembebasan Tanah.

Permendagri No. 2 Tahun 1985 tentang Tata Cara Pengadaan Tanah Untuk Keperluan Proyek Pembangunan Di Wilayah Kecamatan.

Putusan Pengadilan Negeri Bengkulu No.12/1978/Bengkulu.

Keputusan Kepala Badan Pertanahan Nasional No.23/HGU/BPN/90 tentang Pemberian Hak Guna Usaha Atas Nama PT. Bio Nusantara Teknologi Bengkulu. 